\title{
Presence of Ruvettus pretiosus (Gempylidae) in the Colombian continental Caribbean
}

\author{
Maria Camila Gómez-Cubillos, ${ }^{1, *}$, Marcela Grijalba-Bendeck ${ }^{1}$
}

\author{
Edited by \\ Juan Carlos Salcedo-Reyes \\ (salcedo.juan@javeriana.edu.co) \\ 1. Programa de Biología Marina. \\ Facultad de Ciencias Naturales e \\ Ingeniería, Universidad de Bogotá Jorge \\ Tadeo Lozano. Grupo de Investigación \\ en Dinámica y Manejo de Ecosistemas \\ Marino-Costeros DIMARCO. \\ Carrera 2 No. 11-68 Edificio Mundo \\ Marino, Rodadero, Santa Marta \\ (Magdalena) Colombia. \\ *camila_gomezc@hotmail.com \\ Received: 09-07-2015 \\ Accepted: 21-11-2015 \\ Published on line: 25-02-2016
}

Citation: Gómez-Cubillos MC, GrijalbaBendeck M. Presence of Rwvettus

pretiosus (Gempylidae) in the Colombian continental Caribbean,

Universitas Scientiarum, 21 (1): 53-61, 2016. doi: 10.11144/Javeriana.SC21-1.porp

Funding: N/A

Electronic supplementary material: $\mathrm{N} / \mathrm{A}$

OPEN@ACCESS

\begin{abstract}
The first record of Ruvettus pretiosus Cocco, 1833 for the Colombian continental Caribbean is presented. The specimen was collected at Los Cocos, department of Magdalena (11 $16^{\prime} 33,84^{\prime}$ N $73^{\circ} 53^{\prime} 33,01^{\prime}$ W), using a demersal longline gear placed at $100 \mathrm{~m}$ depth. Biometrics, diagnosis and comments regarding its distribution, ecology and biology are included in the description. This new record expands the distribution of the species in the Caribbean Sea and increases the reported number of gempylids for Colombia to five.
\end{abstract}

Keywords: Gempylidae; Ruvettus pretiosus; Caribbean; Colombia; Oilfish.

\section{Introduction}

Biodiversity of marine fauna in the tropical zone is concentrated in two conspicuous peaks, one in the Indo-Pacific Ocean and the other one in the Atlantic Ocean, specifically in the southern Caribbean Sea (Briggs, 2007). This zone acts as a centre of origin and evolutionary radiation and includes the Colombian Caribbean Sea. This zone is characterized by a high fish diversity represented by hard bottom, demersal, and pelagic species, occupying all the available ecosystems, including deep-sea. Despite its importance, fish biodiversity in Colombia is poorly understood and the discovery of a new species must be incorporated into existing databases (Díaz \& Acero, 2003; Rey \& Acero, 2015). Recently, the cataloguing action and the new distributional records have acquired a new urgency through the fact that global biodiversity is changing and declining under multiple mounting threats (Bello et al. 2014). The majority of the marine fishes compromising the existing baseline is related to shallow reef and estuarine areas, with the existing fish fauna in oceanic and deep environments still being relatively unknown (Roa-Varón et al. 2003).

The family Gempylidae, comprising 16 genera and 24 species, is associated with mesopelagic and benthopelagic environments. Gempylids are primarily distributed in tropical, subtropical, and temperate areas worldwide, with little being known about them, both in Colombia and around the world (Nakamura \& Parin, 2002; Lopes et al. 2003). Species included in this family are characterized by short snouts, presenting two nostrils on each side of the head, large and non-protractible mouth, sometimes possessing two strong fang teeth in the upper jaw or a pair in the front of the lower 
jaw. Gempylid species have varying body shape, forked caudal fin, two dorsal fins and finlets. The lateral line is inconspicuous and the skin is notoriously rough. They can reach total lengths of up to $3 \mathrm{~m}$ (Nakamura \& Parin, 2002).

Ruvettus pretiosus Cocco, 1833, is commonly known as oilfish, escolar, escolar clavo or escolar rasposo, and is a benthopelagic species occurring in coastal marine waters at depths of 100-700 $\mathrm{m}$ in the Mediterranean and the Atlantic Ocean south of Bay of Biscay, commonly found near Madeira and the Canaries (Grey, 1953). Worldwide, R. pretiosus has been recorded in the northern Adriatic Sea (Gulf of Trieste) (Bettoso \& Dulčić, 1999; Dulčić et al. 2014), North Eastern Mediterranean Sea (Izmir and Iskenderun Bay) - Turkey (Bilecenoglu et al. 2002; Gurlek et al. 2013) and in the southwestern Indian Ocean (Fricke et al. 2007; 2009). In the western Atlantic it has been reported in Belize (Claro, 1994), Venezuela (Cervigón, 1994); Brazil (CarvalhoFihlo, 1999; Lopes et al. 2003), Gulf of Mexico (McEachran \& Fechhelm, 2005) and Mexican Caribbean (García-Rivas et al. 2013).

Among the known Colombian species of the Gempylidae family, are: Prometichthys prometeus (Acero \& Rueda, 1992), Diplospinnus multistriatus (Roa-Varón et al. 2003), Neoepinnula americana (Roa-Varón et al. 2003), Lepidocybium flavobrunneum (Álvarez-León, 2002). In the Colombian Caribbean Sea, R. pretiosus has been previously reported only for the San Andrés and Providencia Archipelago (Bolaños-Cubillos et al. 2015). No previous reports are available for the species on the continental shelf.

\section{Materials and Methods}

The examined specimen was captured on October 21, 2009 and was part of the

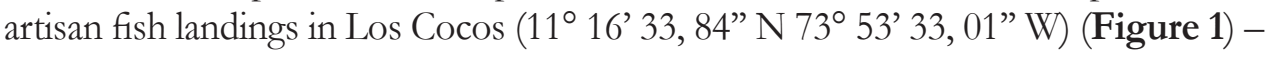

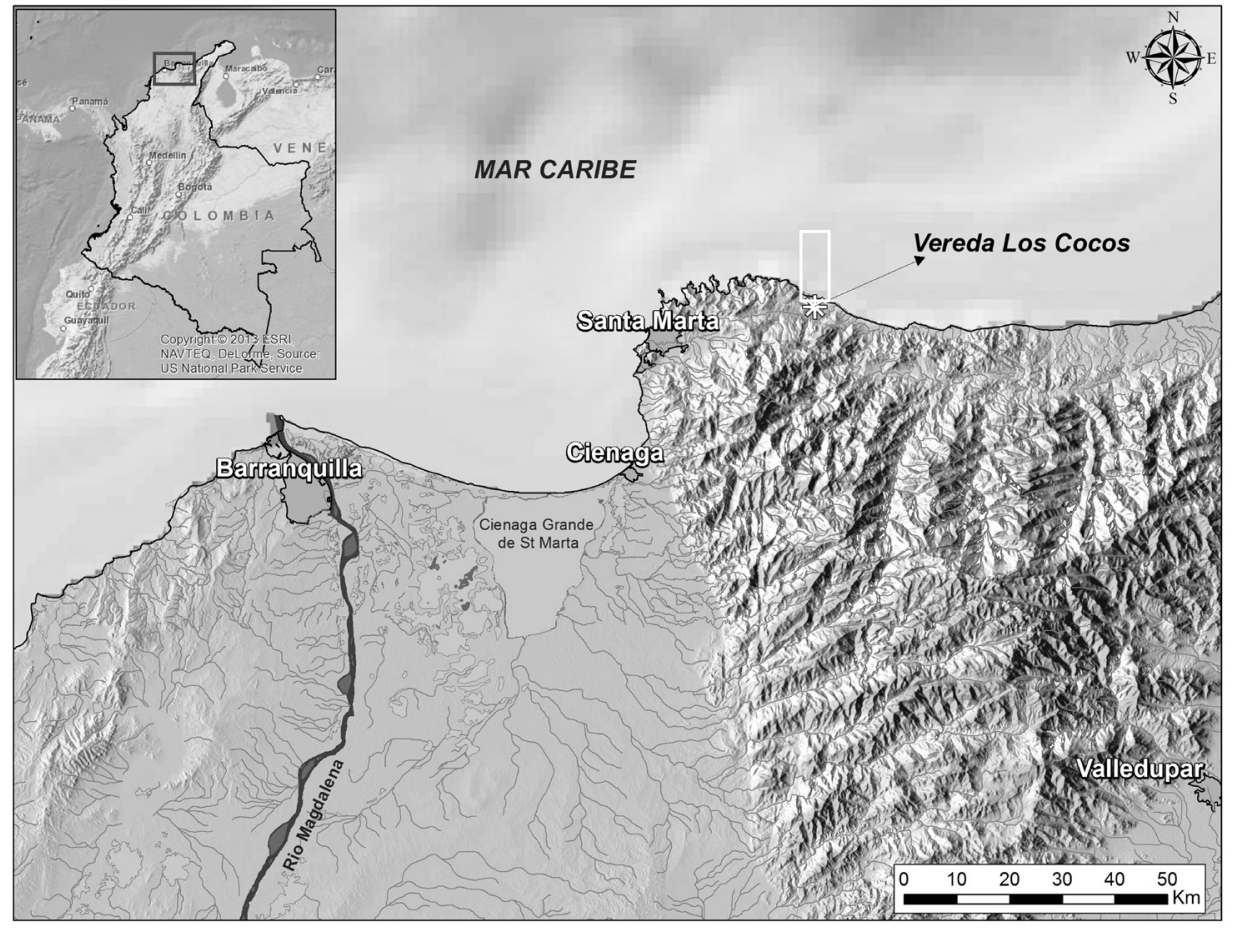

Fig. 1. Map with location of the Los Cocos, Magdalena, Colombia. 
Magdalena Department, Colombian Caribbean. The specimen was obtained using an artisanal demersal horizontal longline, made of nylon and equipped with 200 hooks (No 7) (Cuellar, 2010), and targeted at $100 \mathrm{~m}$ depth. Los Cocos is located in the Colombian Caribbean coast and is under the influence of the north-south movement of the Intertropical Convergence Zone (ZCIT) and the movements of trade winds. These movements lead to upwelling events that increase nutrients in the surface layers, enriching phytoplankton communities and delineating high productivity zones for the area (Franco-Herrera, 2005).

The specimen was analysed at the facilities of the Universidad de Bogotá Jorge Tadeo Lozano, Santa Marta campus. Biometrics (meristic and morphometric data) were collected following Nakamura \& Parin (2002). The specimen was fixed in $4 \%$ formalin, preserved in $70 \%$ alcohol, and introduced into the Colombian Marine Natural History Museum at the Marine and Coastal Research Institute INVEMAR (INV-PEC9011), Fish collection (Figure 2).

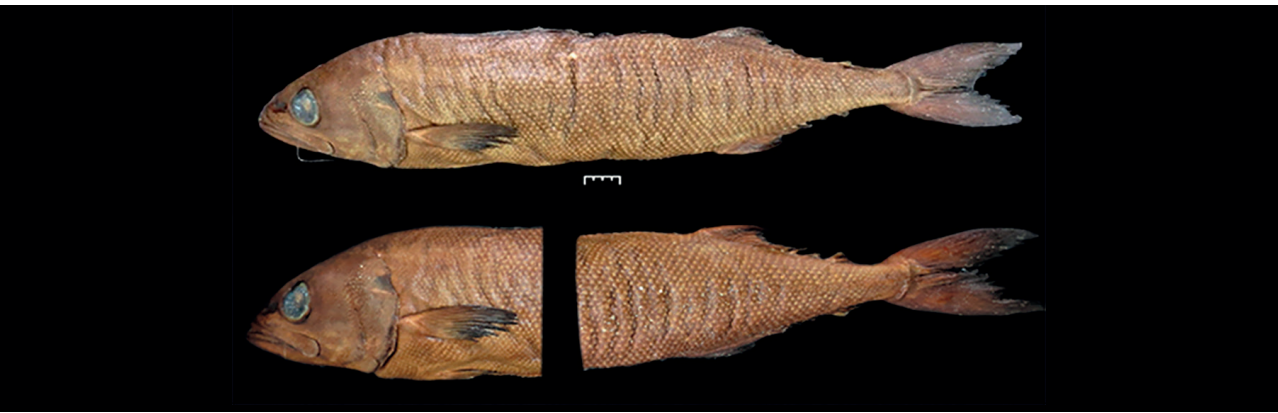

Fig. 2. Ruvettus pretiosus collected in the continental Colombian Caribbean (October 21/2009).

The collected biometric data considered for the species identification followed Bettoso \& Dulčić (1999) and are presented in Table 1.

Table 1. Morphometric data of Ruvettus pretiosus. Measures are given in millimetres (mm).

\begin{tabular}{lc}
\hline MEASURE & Data (mm) \\
\hline Total length & 881 \\
Standard length & 705 \\
Preanal length & 512 \\
Predorsal length & 218 \\
Head length & 208 \\
Snout length & 84 \\
Eye orbit diameter & 40.4 \\
Upper jaw length & 112 \\
Pectoral fin length & 44 \\
Pelvic fin length & 38 \\
Length of anal fin base & 96 \\
Body depth & 145 \\
\hline
\end{tabular}




\section{Results and discussion}

One specimen of $R$. pretiosus was obtained for first time by a coastal artisan fishery during the research project 'Bio-economical valuation of artisanal fisheries with emphasis on the current determination of maturity mean lengths of fish species with commercial importance, in the disembarking sites located between Tasajera and La Jorará (Department of Magdalena).' Detailed information about our documented record is presented below, which is in agreement with the treatment of first record material and related data proposed by Bello et al. (2014) for the first reports in ichthyology.

Identification References: Eschmeyer (2015)

Order Perciformes

Family Gempylidae

Species Ruvettus pretiosus Cocco 1833

Synonymy: Rovetus temminckii, Ruvettus tydemani, Ruvettus whakari, Ruvettus delagoensis, Ruvettus pacificus, Thyrsites acanthoderma, Thyrsites scholaris and Tetragonurus simplex (Eschmeyer, 2015).

Common names: Escolar clavo (Spanish), Oilfish (English), Rouvet (French).

Materials reviewed: One specimen obtained on October 21, 2009 in the coastal

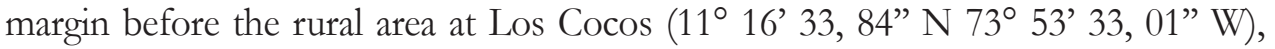
Department of Magdalena, Colombian Caribbean (Figure 1).

Diagnosis: Identification of the specimen followed the characters described by Nakamura \& Parin (1993; 2002), Lopes et al. (2003) and Eschmeyer (2015).

Size: Specimen TL of $881 \mathrm{~mm}$. Keller \& Kerstetter (2014) reported a TL range (cm) between 19.0 and $88.5 \mathrm{~cm}$ from a sample of 56 individuals collected in the Gulf of Mexico and western North Atlantic.

Meristics: First dorsal low XIII to XV spines, second dorsal fin with 15 to 18 soft rays followed by 2 finlets (specimen examined with XIV, 17 and 2 finlets); anal with 15-18 soft rays and followed 2 finlets (specimen: 18 and 2 finlets); pectoral with 15 rays (specimen: 13 rays); pelvic I spine and 5-rays (specimen: I, 15) and devoid of caudal keels (Nakamura \& Parin, 2002).

Morphometrics: Body height is typically 4.3 to 4.9 times the standard length (the specimen examined: 4.6) and the head length 3.3 to 3.7 times the standard length (specimen: 3.5) (Nakamura \& Parin, 2002). Morphometric characteristics of the studied specimen are presented in Table 1.

Coloring: The body of living adults is brown to dark brown and the tips of the pectoral and pelvic fins are black. In juvenile, the edges of the second dorsal and anal fins are white (Nakamura \& Parin, 1993).

Biology and reproduction: $R$ pretiosus migrates during the night for food and feeds on cephalopods and teleost fishes from the orders Gadiformes, Perciformes and Anguilliformes (Vasilakopoulos et al. 2011; Viana et al. 2012). It is a solitary, gonochoristic species with no evidence of sexual reversals being observed. Testes are 
white and ovaries pink. Populations exhibit a bathymetric stratification by sex: males are usually found in deep areas while females inhabit shallower waters in relation to food supply during the spawning period (July - August) (Vasilakopoulos et al. 2011).

Habitat: Pelagic-oceanic, inhabits in all tropical and temperate seas of the world on the upper continental slope (Venu, 2009), within a wide depth range (100-800 m) but usually 200-400 m (Nakamura \& Parin, 2002).

Fishery: Associated with industrial tuna fishing, its catch is very low at the artisanal level (Nakamura \& Parin, 2002).

Distribution: For the western Atlantic it has been reported in the eastern part of Bermuda, Cuba, Haiti and the Florida Keys in the Caribbean (Nakamura \& Parin, 2002); for the Colombian Pacific in Gorgona and Malpelo Islands (Rubio et al. 1992; UNESCO, 2005), but also in the Galapagos Islands and the coastal marine waters of Ecuador and Peru (Cabanilla, 2007).

The presence of $R$. pretiosus described as a macro-carnivorous fish with a calculated trophic level of $4.2 \pm 0.57$ (Fishbase.org) in the continental slope of the Colombian Caribbean Sea, could be related to several areas of high concentration of commercially important deep-sea crustaceans (i.e. Aristaeomorpha foliacea, Pleoticus robustus, Penaeopsis serrata; Metanephrops binghami) located between 200-550 m depth and described in recent studies (Paramo \& Saint-Paul 2012a, 2012b, 2012c). Additionally it could be due to the presence of complex demersal fish assemblages (Paramo et al. 2012). Both factors can be explained by the contribution of important sources of organic matter from the phyto-detritus of the pelagic zone exported from upwelling productive areas to the demersal and deep-sea ecosystems (Rice et al. 1986).

\section{Conclusion}

This manuscript confirms the presence of $R$. pretiosus in the continental waters of the Colombian Caribbean Sea and raises the number of species of the family Gempylidae reported in Colombia to five. This species is rarely found in artisanal fishery catches and occurs in deeps waters, which is why many of its biological and ecological traits are unknown. Future studies on the species and its populations are required in order to determine its role in the demersal fish assemblages.

\section{Acknowledgments}

The authors are grateful to the fishermen community at Los Cocos for providing the specimen examined, in particular to Ángel Arroyo, Ángel Arroyo Jr. and Ángel Moreno. Also, to D. Kieckbusch for his useful comments on the manuscript. This manuscript is a contribution of the Grupo de Investigación de Dinámica y Manejo de Ecosistemas Marino-Costeros DIMARCO of the Marine Biology Program at the UTadeo, Santa Marta campus. Financial support was provided by the Colombian Ministry of Agriculture and Rural Development (Ministerio de Agricultura y Desarrollo Rural de Colombia) (CONTRACT No 2007T6682 289/07), the Universidad de Bogotá Jorge Tadeo Lozano (UTadeo), CoopesTaganga, Aunap (Incoder),

Museo del Mar Foundation and SilaKangama.

\section{Conflict of interest}

This paper does not present any conflict of interest. 


\section{References}

Acero P, Rueda A. Presencia de Promethichthys prometheus (Cuvier) (Pisces: Gempylidae) en el Caribe colombiano. Anales del Instituto de Investigación Marina, Punta Betín 21: 127-130, 1992. Retrieved from: http://www.scielo.org.co/scielo.php?pid=S012297611992000100010\&script $=$ sci_arttext

Álvarez-León R. Capturas comerciales con palangre en la zona económica exclusiva frente a la Guajira, Caribe de Colombia. Revista Biología Tropical 50: 227-231, 2002.

Bello G, Causse R, Lipej L, Dulčić J. A proposed best practice approach to overcome unverified and unverifiable "first records" in ichthyology. Cybium, 38: 9-14, 2014.

Bettoso N, Dulčić J. First record of the oilfish Ruvettus pretiosus (Pisces: Gempylidae) in the northern Adriatic Sea. Journal of the Marine Biological Association of the United Kingdom 79: 1145-1146, 1999. doi: $10.1017 /$ S0025315499001496

Bilecenoglu M, Taskavak E, Mater S, Kaya M. Checklist of the marine fishes of Turkey. Zootaxa 113: 1-194, 2002.

Bolaños-Cubillos N, Abril-Howard A, Bent-Hooker H, Caldas JP, Acero A. Lista de peces conocidos del archipiélago de San Andrés y Providencia, Caribe occidental colombiano. Boletin de Investigaciones Marinas y Costeras 44: 127-162, 2015.

Briggs JC. Marine longitudinal biodiversity: causes and conservation. Diversity and distributions. 13: 544-555, 2007. doi: $10.1111 /$ j.1472-4642.2007.00362.x

Cabanilla C. Seguimientos de los desembarques de peces pelágicos grandes durante el 2007. Instituto Nacional de Pesca. Ecuador. 13p, 2007.

Carvalho - Fihlo A. Peixes da Costa Brasileria Sao Paulo, Melro, 136 p, 1999.

Cervigón F. Los peces marinos de Venezuela. Fundación Científica Los Roques. v. 3: 1-295, 1994.

Claro R (Ed.) Ecología de los peces marinos de Cuba. Chetumal: Academia de Ciencias de Cuba/Centro de Investigaciones de Quintana Roo. 1994.

Cuellar J. Caracterización de la actividad pesquera, aportando algunos aspectos bioeconómicos para el sector comprendido entre Taganga y La Jorará, (Magdalena, Caribe colombiano), Agosto (2008) Febrero (2009). Tesis de grado para optar por el titulo de biólogo marino. Programa de Biología Marina, Facultad de Ciencias Naturales e Ingeniería. Universidad de Bogotá Jorge Tadeo Lozano. Santa Marta. 79 p, 2010.

Retrieved from: http://unicornio.utadeo.edu.co/tesis/biologia_marina/T919.pdf

Díaz JM, Acero A. Marine biodiversity in Colombia: achievements, status of knowledge and challenges. Biodiversidad marina en Colombia: Estado actual del conocimiento y desafíos futuros Gayana, 67: 261-274, 2003. doi: 10.4067/S0717-65382003000200011

Dulčić J, Dragičević B, Pavičić M, Ikica Z, Joksimović A, et al. Additional records of nonindigenous, rare and less known fishes in the eastern Adriatic. Annales Series Historia Naturalis 24: 17-22, 2014.

Eschmeyer WN, and Fricke R. (eds). Catalog of Fishes. Database: Species. [This version was edited by Bill Eschmeyer.] Retrieved from: http://researcharchive.calacademy.org/ research/ichthyology/catalog/fishcatmain.asp Electronic version accessed 02102015.

Franco-Herrera A. Oceanografía de la ensenada de Gaira: El Rodadero, más que un centro turístico en el Caribe Colombiano. Universidad de Bogotá Jorge Tadeo Lozano, Santa Marta, Colombia. pp. 562005. 
Fricke R, Bilecenoglu M, Sari HM. Annotated checklist of fish and lamprey species (Gnathostomata and Petromyzontomorphi) of Turkey, including a Red List of threatened and declining species. Stuttgarter Beiträge zur Naturkunde Ser A. No 706: 169, 2007.

Fricke R, Mulochau T, Durville P, Chabanet P, Tessier E et al. Annotated checklist of the fish species (Pisces) of La Réunion, including a Red List of threatened and declining species. Stuttgarter Beiträge zur Naturkunde A, Neue Serie, 2: 1-168, 2009.

García-Rivas MC, Schmitter-Soto JJ, Pérez-Flores J. Fatal predation of oilfish, Ruvettus pretiosus (Gempylidae), by a young short-finned pilot whale, Globicephala macrorbynchus (Delphinidae). Cuadernos de Investigación UNED. 5: 1-3, 2013.

Grey M. Fishes of the family Gempylidae, with records of Nesiarchus and Epinnula from the western Atlantic and description of two new subspecies of Epinnula orientalis. Copeia, 3: 135-141, 1953. doi: $10.2307 / 1439918$

Gurlek M, Erguden D, Turan C. Occurrence of the oilfish, Ruvettus pretiosus Cocco, 1833 (Gempylidae) in Iskenderun Bay, northeastern Mediterranean, Turkey. Jounal of Applied. Ichtbyology 29: 1158-1159, 2013.

doi: $10.1111 /$ jai.12202

Keller H, Kerstetter D. Length-length and length-weight relationships of oilfish (Ruvettus pretiosus), escolar (Lepidocybium flavobrunneum), snake mackerel (Gempylus serpens), and longnose lancetfish (Alepisaurus ferox) from the Gulf of Mexico and the western North Atlantic Ocean, Journal of Applied Icbthyology 30: 241-243, 2014. doi: $10.1111 /$ jai.12229

Lopes P, Oliveira-Silva J, Sampaio C, Olavo G. Registros de Gempylus serpens Cuvier, 1829, Lepidocybium flavobrunneum (Smith, 1849) e Ruvettus pretiosus Cocco, 1829 (Actinopterygii: Gempylidae) no litoral do Estado da Bahia, Brasil. Arqivos de Ciências do Mar, Fortaleza, 36: 45-48, 2003.

McEachran JD, Fechhelm JD. Fishes of the Gulf of Mexico. Vol 2: Scorpaeniformes to Tetraodontiformes. College Station: University of Texas Press, pp. 1120, 2005.

Nakamura I, Parin N. FAO Species Catalogue. Vol 15. Snake makerels and cutlassfishes of the world (Families Gempylidae and Trichiuridae). An annotated and ilustrated catalogue of the snake mackerels, snoeks, escolars, gemfishes, sackfishes, domine, oilfish, cutlassfishes, scabbardfishes, hairtail, and frostfishes known to date. FAO, Rome, pp. 136, 1993.

Nakamura I, Parin N. Gempylidae, Snake mackerels (Scolars, Oilfisch), P.P. Shirshov Institute of Oceanology, Russia. Kyoto University, Japan. In: Carpenter, K.E. (Ed.). The living marine resources of the Western Central Atlantic. Vol 3: Bony fishes part 2 (Opistognathidae to Molidae), sea turtles and marine mammals. FAO Species Identification Guide for Fishery Purposes and American Society of Ichthyologists and Herpetologists Special Publication No. 5. Food and Agriculture Organization of the Unite Nations -FAO-. Roma. pp. 1374-2055 p. 2002.

Paramo J, Saint-Paul U. Spatial structure of the pink speckled deep-sea shrimp Penaeopsis serrata (Bate, 1881) (Decapoda, Penaeidae) during November-December 2009 in the Colombian Caribbean Sea. Crustaceana, 85: 103-116, 2012a.

doi: $10.1163 / 156854012 X 623665$

Paramo J, Saint-Paul U. Spatial structure of deep-sea lobster (Metanephrops binghami) in the Colombian Caribbean Sea. Helgoland Marine Research, 66: 25-31, 2012b. doi: 10.1007/s10152-011-0243-6

ParamoJ, Saint-Paul U.Deep-sea shrimps Aristaeomorphafoliacea and Pleoticus robustus (Crustacea: Penaeoidea) in the Colombian Caribbean Sea as a new potential fishing resource. Journal of the Marine Biological Association of the United Kingdom, 92: 811-818, 2012c. doi: 10.1017/S0025315411001202 
Paramo J, Wolff M, Saint-Paul U. Deep-sea fish assemblages in the Colombian Caribbean Sea. Fisheries Research, 125-126: 87-98, 2012.

doi: 10.1016/j.fishres.2012.02.011

Rice AL, Billett DS, Fry J, John AW, Lampitt RS, Mantoura R.F, Morris R.J. Seasonal deposition of phytodetritus to the deep-sea floor. Proceedings Royal Society Edinburgh, 88B, 265-279, 1986.

doi: $10.1017 / \mathrm{S} 0269727000004590$

Rey I, Acero A. Biodiversidad íctica del Caribe Colombiano. Universidad de Bogotá Jorge Tadeo Lozano. [recurso electrónico]. 2015.

Roa-Varón A, Saavedra-Díaz L, Acero A, Mejía L, Navas G. Nuevos registros de peces óseos para el Caribe Colombiano de los órdenes Beryciformes, Zeiformes y Tetraodontiformes. Boletin de Investigaciones Marinas y Costeras, 32: 3-24, 2003.

Rubio E, Suárez A, Estupiñán F, Henao W, Vargas B. Los recursos ictiológicos de la Isla de Malpelo (Colombia). I. Una revisión de su conocimiento y nuevos reportes para la ictiofauna de la Isla. Memorias. VIII Seminario. Nacional de Ciencias y Tecnología del. Mar, CCO, Bogotá: pp 642-658, 1992.

UNESCO. Gorgona and Malpelo Islands, Coastal and Oceanic National Marine Parks of Colombia's Eastern tropical Pacific. Valle del Cauca - Colombia. pp. 592, 2005.

Vasilakopoulos P, Pavlidis M, Tserpes G. On the diet and reproduction of the oilfish Ruvettus pretiosus (Perciformes: Gempylidae) in the eastern Mediterranean. Journal of the Marine Biological Association of the United Kingdom, 91: 873-881, 2011.

doi: 10.1017/S0025315410001785

Venu S. The systematics, distribution and bionomics of deep-sea fishes beyond depth $200 \mathrm{~m}$ along the south west coast of India coast of India. Thesis School of Industrial Fisheries. Cochin University of Science and Technology, Kochi. pp. 426, 2009. Retrieved from: http://dyuthi.cusat.ac.in/xmlui/handle/purl/3642

Viana D, Tolotti M, Porto M, Araújo R, Vaske T, Jr Hazin F. Diet of the oilfish Ruvettus pretiosus (Perciformes: Gempylidae) in the Saint Peter and Saint Paul Archipelago, Brazil. Brazilian Journal of Oceanography 60: 181-188, 2012. 
Presencia de Ruvettus pretiosus (Gempylidae) en el Caribe continental colombiano

Resumen. Se presenta el primer registro de Ruvettus pretiosus Cocco, 1833, para el Caribe colombiano continental. El especimen fue colectado en Los Cocos, Departamento de Magdalena, $\left(11^{\circ} 16^{\prime} 33\right.$, $84^{\prime}$ N $73^{\circ} 53^{\prime} 33,01^{\prime}$ W), usando un palangre sumergible colocado a $100 \mathrm{~m}$ de profundidad. En la descripción se incluye biometría, diagnóstico y comentarios sobre su distribución, ecología y biología. Este nuevo registro amplía la distribución de la especie en el Mar Caribe e incrementa a cinco el número de gempílidos reportados en Colombia.

Palabras clave: Gempylidae; Ruvettus pretiosus; Caribe; Colombia; pez aceitero.

\section{Presencia de Ruvettus pretiosus (Gempylidae) no Caribe continental colombiano}

Resumo. É apresentado o primeiro registro de Ruvettus pretiosus Cocco, 1833, para o Caribe Colombiano continental. O espécime foi capturado na vereda Los Cocos, Departamento de Magdalena (11 $11^{\circ}$ $33,84^{\prime}$ N $73^{\circ} 53^{\prime} 33,01^{\prime}$ W), utilizando palangres horizontais demersales a uma profundidade de $100 \mathrm{~m}$. Estão incluídos neste manuscrito dados biométricos, diagnóstico das espécies e comentários sobre a sua distribuição, ecologia e biologia. Com este novo reporte a distribuição das espécies no Mar do Caribe se expande, aumentando para cinco o números de espécies da família Gemphelidae na Colômbia.

Palavras-chave: Gempylidae; Ruvettus pretiosus; Caribe Colombiano; Oilfish.

Maria Camila Gómez-Cubillos

Marine Biologist, M.Sc Candidate in Environmental Sciences with emphasis on water resources management. Specialist in Environmental Law. Research interests focus on fish reproductive, biology and environmental toxicology with emphasis on fish community, determining how pollution is affecting these organisms emphasizing histological and biochemical processes.

\section{Marcela Grijalba-Bendeck}

Marine Biologist, Ph.D Candidate, Assistant Professor Marine Biology B.Sc.and Marine Conservation M.Sc Program from the Universidad de Bogotá Jorge Tadeo Lozano, Santa Marta Campus. Research interests are taxonomy of neotropical marine fish, fish physiology, fisheries, fish bioecology, deep-sea fisheries and in the impacts of unburnt coal on coastal marine ecosystem but also in the strong links between the research community, fishermen, industry and policy. 